Futile Pleasures 
This page intentionally left blank 


\section{Futile Pleasures}

Early Modern Literature AND THE Limits OF UTILITY

Corey McEleney

F O R D A M UN IVERSITY PRES S

New York 2017 


\section{Copyright @ 2017 Fordham University Press}

All rights reserved. No part of this publication may be reproduced, stored in a retrieval system, or transmitted in any form or by any meanselectronic, mechanical, photocopy, recording, or any other-except for brief quotations in printed reviews, without the prior permission of the publisher.

Fordham University Press has no responsibility for the persistence or accuracy of URLs for external or third-party Internet websites referred to in this publication and does not guarantee that any content on such websites is, or will remain, accurate or appropriate.

Fordham University Press also publishes its books in a variety of electronic formats. Some content that appears in print may not be available in electronic books.

Visit us online at www.fordhampress.com.

Library of Congress Cataloging-in-Publication Data

Names: McEleney, Corey, author.

Title: Futile pleasures : early modern literature and the limits of utility / Corey McEleney.

Description: New York : Fordham University Press, 20 1 7. I Includes bibliographical references and index.

Identifiers: LCCN 2016013983 | ISBN 9780823272655 (hardback) I ISBN 9780823272662 (paper)

Subjects: LCSH: English literature-Early modern, I 500-I 700-History and criticism. I Pleasure in literature. I Senses and sensation in literature.

| Literature and society-England-History-I6th century. I Literature and society-England-History - I 7 th century. I BISAC: LITERARY CRITICISM / Renaissance. I SOCIAL SCIENCE / Gender Studies.

Classification: LCC PR42 I .M29 2017 I DDC 820.9/o03-dc23

$\mathrm{LC}$ record available at https://lccn.loc.gov/20I60I3983

Printed in the United States of America

$$
\begin{array}{llllllll}
\text { I9 } & \text { I } 8 & \text { I7 } & 5 & 4 & 3 & 2 & \text { I }
\end{array}
$$

First edition 
for Chris Holmes 
This page intentionally left blank 